\title{
Comparison and some similarities between Polish language and Iranian languages (case study of Old Persian, Pahlav, Middle Persian and Lori language)
}

https://doi.org/10.34739/his.2019.08.16

\begin{abstract}
In general the Slavic languages has a lot in common with old Iranian languages. As Polish language and some Iranian languages are a branch of the Indo-European language family. The similarity between two languages seems to be possible. This brief note could give new insight in Indo European cultural relations.
\end{abstract}

Key words: Lori, Old Persian, Pahlav, Middle Persian, Polish, language, God, brother, high, earth

\section{Introduction}

Lori is a language of one of Iran's major ethnic groups, belonging to IndoIranian branch of Indo-European group. The Lori dialects belong, together with Persian, to the southern branch of Western Iranian. It abridges Kurdish and Persian in a linguistic continuum. Both Lori and Kurdish are spoken by both settled and nomadic population over a large area of western Iran ${ }^{1}$. The ancient region of Lorestān is located in the mountainous area of Zagros, close to the border of the Iraq. In wider sense, it consists of the part of western Iran coinciding with the province of Ilam, and extends from Kermanshah to Fars ${ }^{2}$. Lorestān was successfully integrated into the Achaemenid, Parthian and Sasanian empires ${ }^{3}$. Lori language includes many ancient words which

\footnotetext{
* ORCID iD 0000-0003-4200-2592. karamianreza@yahoo.com; In 2018 I have been accepted as an research fellow in PIASt (Polish Institute of Advance Studies) for working on ancient Iranian study with special reference to Parthian and Sasanian periods. As I started learn polish language, I have seen unbelievable similarity between Lori, Polish language and ancient Iranian languages.

** ORCID iD 0000-0001-8709-0333. szapur2@ poczta.onet.pl

${ }^{1}$ KERIMOVA 1982; SUNDERMANN 1989; MACKINNON 2011; ANONBY 2012: 'The array of related dialects collectively known as Lori (autonym: lurī)'.

${ }^{2}$ MORTENSEN, MORTENSEN 2014.

${ }^{3}$ FRYE 1984.
} 
have survived since Parthian and Sasanian periods up to present time. A book published in 2013 by Karamian in Farsi (title eng. Parthian and Sasanian words in Lori Language) provides a study of such parallels, based on reading of ancient inscriptions and written resources from remaining Pahlav or Middle Persian texts ${ }^{4}$. The present paper documents sample similarities between Polish and Lori, Old Persian, Pahlav and Middle Persian.

\section{Trace of Polish word Bóg in the inscription of king Darius I in Naqšs-e Rostam}

Darius I the Great was the third Achaemenid king of kings (r. 29 September 522-October $486 \mathrm{BC})^{5}$. He was buried at Naqš-e Rostam ${ }^{6}$. The famous inscription of Darius I was made c.490 BC, and it is placed in the top left corner of the facade of the tomb of the king?

DNa 1-4:

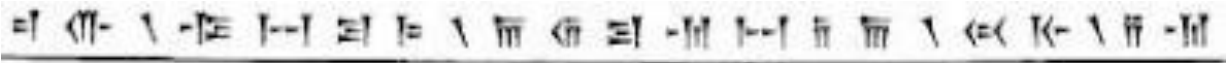

$$
\begin{aligned}
& \text { 两 }-\pi \text { । }
\end{aligned}
$$

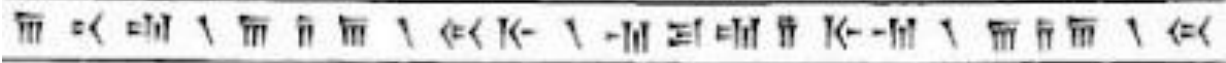

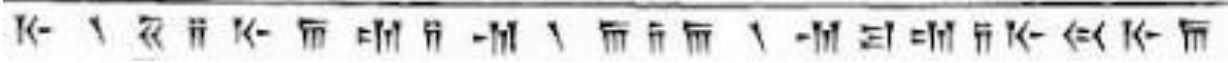

Transliteration:

baga \vazraka \Auramazdâ \hya \imâm \bumâm \adâ \hya \avam \asmânam \adâ \ hya \martiyam \adâ \hya \šiyâtim \adâ \martiyahyâ

English translation:

'A great god is Ahuramazda, who created this earth, who created yonder sky, who created man, who created happiness for man, who made Darius king, one king of many, one lord of many'.

The first line of the inscription start with word Baqa $=$ " (II- , which means 'God'. This word means 'God' not only in Old Persian, but in Middle Persian or Pahlav. The word used presently in Lori as Bag also means 'God'. Nyberg refers to $\boldsymbol{B a g}$ as a Middle Persian word meaning ' $\mathrm{God}^{7}{ }^{8}$, just as Lori word $\boldsymbol{B a g}^{9}$. It is interesting

\footnotetext{
${ }^{4}$ KARAMIAN 2013.

${ }^{5}$ SHAHBAZI 1994.

${ }^{6}$ VON GALL 2009.

${ }^{7}$ HULSTAERT 1974: 23.

${ }^{8}$ NYBERG 1964: 42; $\boldsymbol{b a y}$ in MACKENZIE 1971: 17.

${ }^{9}$ KARAMIAN 2013: 53.
} 
to note that this word is not in use in modern Farsi (official language of Iran), but Bag is still in use in Lori and Polish where it took the form Bóg meaning 'God'.

\section{Polish word brat in the Pahlav and Middle Persian text}

Polish word brat means 'brother' similar to berār, brät, brād all means 'brother' in Lori and Laki languages, which are still in use in the Lorestān province ${ }^{10}$. This word can be found in the third line of Avroman Parthian text (AV3) ${ }^{11}$, a parchment found in a cave in the Kūh-e Sālān, near Avroman (on the western frontier of Persian Kurdistan), dated to $33 \mathrm{AD}^{12}$.

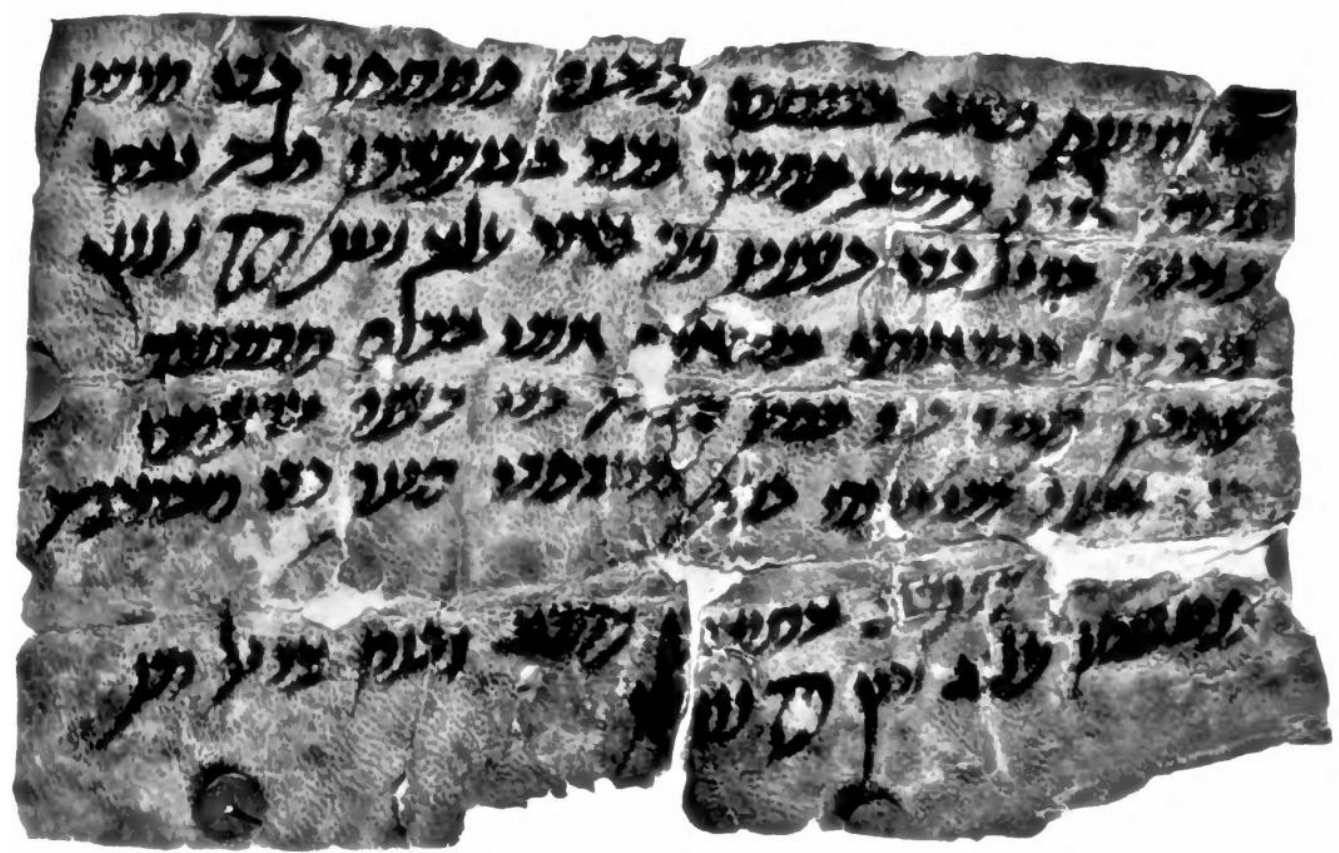

AV3; after MINNS 1915: pl. III

Transliteration:

sarס 300, māh (h)arwatāt frawaxšed pātasbag pu tīrēn.

čē až (...?) raz asmag čē abikaškan nēm yād.

ūd xarīnēd awīl puhr bašnīn...brād har drahm 65 .

če až būm-xwad sōgand ham xwarēd parwān.

wigāhān tīrag puhr ārpīn...puhr rašn arštād.

\footnotetext{
${ }^{10}$ NYBERG 1964: 49; MACKENZIE 1971: 19; MACKINNON 2011; KARAMIAN 2013: 52.

${ }^{11}$ HACKL, JACOBS, WEBER 2010: 556.

${ }^{12}$ MACKENZIE 1987.
} 
puhr abān gar-panah puhr mihr-frī sēnag puhr mātbōg.

raz...asmagān raz xrīd awīl až

pātasbag har drahm 65.

English translation:

'In the year 300 in the month of Arwatat, Pataspak son of Tirin, who [comes] from Bod, sold half the vineyard of Asmak, which is by the ploughfields, and Awil son of Bashnin as brother bought [it] fo[r] a total of 65 drachmae, which was charged by the owner. He also swore before the witnesses: Tirak son of Apen, M...g(?) son of Rashn, Arshtat s[on] of Aban, Garpanah son of Mihrfriy, Senak son of Matbog. [......] vineyard, Awil bought the vineyard of Asmakan from Pataspak for a total of 65 drachmae.'

The word brād is also mentioned in Kartīr's Middle Persian inscriptions in Fārs at Naqš-e Rostam (KNRm) ${ }^{13}$, to the right of Shapur I's (r. 242-272) triumphal relief. Kartīr was a prominent Zoroastrian mowbed in the second half of the $3^{\text {rd }}$ century CE. KNRm had been engraved in c. $290^{14}$.

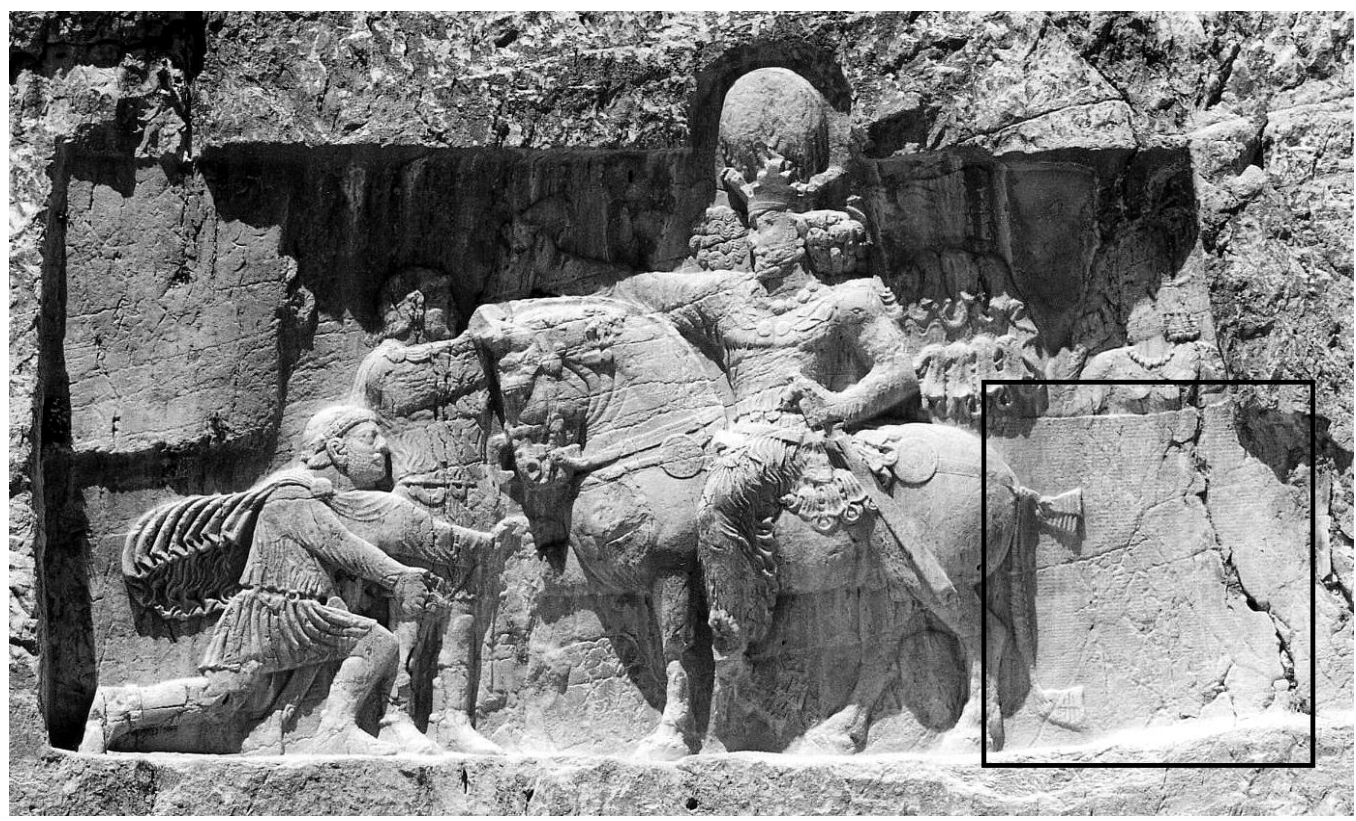

ŠābuhrI's triumphal relief at Naqš-e Rostam

\footnotetext{
${ }^{13}$ MACKENZIE 1989.

${ }^{14}$ SKJÆRVØ 2011.
} 


\section{KNRm 7:}

Transliteration:

ud pas kū Ohrmezd šāhān šāh ō bayān gāh šud ud Wahrām šāhān šāh i Šābuhr pus ud Ohrmezd šāhān šāh brād pad šahr ēstēd

English translation:

'And after Hormizd, king of kings, went to the place of the gods and Bahram, king of kings, son of Shapur, king of kings, and brother of Hormizd, king of kings, established himself in the kingdom.'

\section{Trace of polish word bardzo in the Middle Persian text}

Polish word bardzo means a 'lot', and reveals strong similality to barz which means 'high' in Lori. It seems that both words have a root in Sasanian texts. The word borz can be also found in the Middle Persian inscriptions where it also mean 'high' 15 . Different forms of this word can be found in the Sasanian texts. The deity Apąm Napāt ${ }^{16}$ is also known, as Burz, Borz or Borj, being a reduction of Avestan borozant-, the 'high one'. Henning translates the meaning word as burz 'high, tall'17. 'In the course of oral transmission by speakers of Middle Persian, the Parthian text came to include many words or constructions influenced by this language, for example, buland high, tall (instead of burzend) ${ }^{18}$. This word is written with Middle Persian script in Pahlavi text as $\underline{\boldsymbol{\nu}_{\boldsymbol{1}}}$.

Sīh Rōzag 1, Gāh 3:

Transliteration:

Burz $\overline{1}$ xwadāy [ī mādagān $\overline{1}$ rōšn] $\overline{1}$ ābānnāf, ābiz $\overline{1}$ ohrmazddād

English translation:

'(of) Burz, lord [of women, luminous], of the family of the waters, and (of) water, created by Ohrmazd.'

\section{Polish word Ziemia and Lori word Zemi}

Lori word zemi and Polish word ziemia both mean 'earth'. It is interesting to note that the word $\boldsymbol{z a m} \overline{\boldsymbol{a}} \boldsymbol{g}$ from the Middle Persian text has same meaning ${ }^{19}$.

\footnotetext{
15 MACKENZIE 1971: 19; KARAMIAN 2013: 53.

${ }^{16}$ BOYCE 1986.

${ }^{17}$ HENNING 1950: 643, n. 12.

${ }^{18}$ TAFAŻŻOLĪ 1995.

${ }^{19}$ MACKENZIE 1971: 98; 146; KARAMIAN 2013: 11.
} 


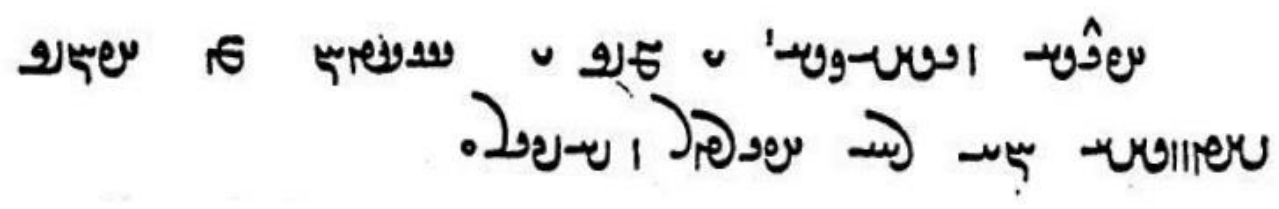

Transliteration:

abdīh ud sahīgīh $\overline{1}$ zamīg $\overline{1}$ sagestān az abārīg šahrīhā ēd rāy abērdar ud veh

English translation:

'The wonders and mirabilia of the land of Sakastāna are much more and better than other provinces, for these reasons'.

\section{Conclusion}

In general the Slavic languages have a lot in common with the old Iranian languages. The Polish language and some Iranian languages are a branch of the IndoEuropean language family, which would have been spoken several millennia earlier somewhere, perhaps, in the area of southern Russia. The similarity between two languages seems to be possible. Hopefully, this brief note could give new insight in Indo European cultural relations.

\section{Bibliography}

ANONBY E. (2012), 'Lori language ii. Sociolinguistic Status of Lori', Encyclopcedia Iranica, online edition, available online at http://www.iranicaonline.org/articles/lori-language-ii (accessed on 30 June 2019).

BOYCE M. (1986), 'Apąm Napāt', Encyclopaedia Iranica 2.2, 148-150.

FRYE R.N. (1984), The History of Ancient Iran, München.

HACKL U., JACOBS B., WEBER D., (2010), eds. Quellen zur Geschichte des Partherreiches: Textsammlung mit Übersetzungen und Kommentaren, bd. 2: Griechische und lateinische Texte, parthische Texte, numismatische Evidenz, Göttingen.

HENNING W.B. (1950), 'A Pahlavi Poem', Bulletin of the School of Oriental and African Studies 13, 641-648.

HULSTAERT L. (1974), 'DPe 13-15 and DB I, 15-17 reconsidered', Orientalia Lovaniensia Periodica 5. 21-29.

KARAMIAN G. (2013), Parthian and Sasanian words in Lori Language, Tehran (in Farsi).

KERIMOVA A.A. (1982), 'Lurskie i Bakhtiyarskie Dialekty', in Osnovy iranskogo yazykoznaniya. Novoiranskie yazyki II, Moscow, 287-315.

MACKENZIE.D.N, (1971), A concise Pahlavi dictionary, London and New York.

MACKENZIE.D.N, (1987), 'Avroman documents', Encyclopaedia Iranica 3.1, 111.

MACKINNON C. (2011), 'Lori language i. Lori Dialects', Encyclopcedia Iranica, online edition, available online at http://www.iranicaonline.org/articles/lori-dialects (accessed on 30 June 2019). 
MINNS E.H. (1915), 'Parchments of the Parthian Period from Avroman in Kurdistan', The Journal of Hellenic Studies 35, 22-65.

MORTENSEN I.D., MORTENSEN P. (2014), 'Luristan iv. The Origin of Nomadism,' Encyclopcedia Iranica, online edition, available at http://www.iranicaonline.org/articles/luristan-04-origin-nomadism (accessed on 26 August 2014)

NYBERG H.S. (1974), A Manual of Pahlavi, Wiesbaden.

SHAHBAZI A.S. (1994), 'Darius iii. Darius I the Great', Encyclopaedia Iranica 7.1, 41-50.

SKJÆRVØ P.O. (2011), 'Kartir', Encyclopcedia Iranica 15.6, 608-628,

SUNDERMANN W. (1989), 'Westmitteliranische Sprachen', in Compendium Linguarum Iranicarum, ed. R. SCHMITT, Wiesbaden, 106-13.

TAFAŻŻOLĪ A. (1995), 'Draxt 1 ìsūrūg', Encyclopaedia Iranica, 7.5, 547-549.

VON GALL H. (2009), 'Naqš-e Rostam', Encyclopcedia Iranica, online edition, available online at http://www.iranicaonline.org/articles/naqs-e-rostam (accessed on 30 June 2019). 